\title{
PERUBAHAN SOSIAL PADA PETANI KELAPA (Studi kasus Petani Kelapa di Desa Senduk, Kecamatan Tombariri)
}

\author{
Richi Romel Sembel \\ Martha M. Sendow \\ Welson M. Wangke \\ Jean F.J. Timban
}

\begin{abstract}
The purpose of this study was to determine how social changes in the lives of coconut farmers in the village Senduk over the last 10 years. This study uses a case study. Data collected in the form of primary data and secondary data. Primary data was collected by means of in-depth interviews on 20 respondents who are coconut farmers. The primary data is regarding the farmer characteristics and the occuring of social change process. While secondary data such as population growth comes from the Senduk village office. Primary data were analyzed descriptively. The research results showed that social change in the form of social order has been a shift. In this case the shift in social norms that lead to behavioral changes in Senduk coconut farmers in the village. The results showed that social change in the form of social order has been a shift. In this case the shift in social norms that lead to behavioral changes in society Senduk coconut farmers in the village. Likewise, there has been a change in people's lifestyles, people are more likely to implement a consumptive lifestyle. Coupled with the influx of new technologies have led to reduce a directly social interaction and also farmers began to abandon their traditions. Population growth that occurred over the last 10 years has led to an increase in density which in turn leads to the village of Senduk government should expand the area of new settlements. The expansion of residential areas has an impact on agricultural land with the narrowing of agricultural land due to the transfer of use of agricultural land to residential land.
\end{abstract}

Key words: Social change, coconut farmers, Tombariri

Tujuan dari penelitian ini adalah untuk mengetahu terjadinya perubahan sosial dalam kehidupan petani kelapa di Desa Senduk selama 10 tahun terakhir. Penelitian ini menggunakan studi kasus. Data yang dikumpulkan dalam bentuk data primer dan data sekunder. Data primer dikumpulkan dengan cara wawancara mendalam pada 20 responden yang merupakan petani kelapa. Data primer menyangkut karakteristik petani dan terjadinya proses perubahan sosial. Sedangkan data sekunder berasal dari Kantor desa Senduk berupa data pertumbuhan penduduk. Data primer dianalisis secara deskriptif. Hasil penelitian menunjukkan bahwa perubahan sosial dalam bentuk tatanan sosial telah terjadi pergeseran. Dalam hal ini pergeseran norma-norma sosial yang mengarah pada perubahan perilaku di petani kelapa di Desa Senduk. Hasil penelitian menunjukkan bahwa perubahan sosial dalam bentuk tatanan sosial telah pergeseran. Dalam hal ini pergeseran norma-norma sosial yang mengarah pada perubahan perilaku di masyarakat petani kelapa di Desa Senduk. Demikian juga, telah terjadi perubahan gaya hidup masyarakat, masyarakat desa lebih cenderung untuk menerapkan gaya hidup konsumtif. Ditambah dengan masuknya teknologi baru telah mengurangi interaksi sosial langsung dan juga petani mulai meninggalkan tradisi yang sebelumnya mereka lakukan. Pertumbuhan penduduk yang terjadi selama 10 tahun terakhir telah menyebabkan peningkatan kepadatan yang pada gilirannya mendorong pemerintah Desa Senduk harus memperluas wilayah permukiman baru. Perluasan daerah pemukiman telah berdampak pada lahan pertanian dengan terjadinya penyempitan luas lahan pertanian akibat terjadinya alih fungsi penggunaan dari lahan pertanian menjadi lahan pemukiman.

Kata kunci: Perubahan sosial, petani kelapa, Kecamatan Tombariri

\section{PENDAHULUAN}

\section{Latar Belakang}

Setiap manusia selama hidup tak pernah lepas dari perubahan-perubahan masyarakat yang mencakup nilai-nilai dan norma-norma sosial, pola perilaku, organisasi, susunan lembaga kemasyarakatan, lapisan-lapisan dalam masyarakat kekuasaan dan wewenang, interaksi sosial dan lain sebagainya.
Hal ini dimungkinkan karena adanya tuntutan jaman yang mengarahkan pada hal-hal baru, menarik, praktis serta profesional. Mengamati dan mengevaluasi perubahan yang terjadi, ada yang lambat ada pula yang cepat, ada yang menarik ada pula yang tidak menarik dalam arti kurang cocok bagi masyarakat lainnya. Namun pada dasarnya perubahan tersebut dapat terjadi dari waktu ke waktu. Dengan maksud bahwa setiap era perubahan 
jika diikuti dengan berbagai instrumen yang tersebut.

Kajian lainnya bahwa ada masyarakat yang mengikuti perubahan karena menginginkan sesuatu yang praktis, namun prinsip harus diikuti dengan dukungan material yang cukup serta sumber daya yang mampu menepis tantangan yang ada. Soekanto (2013) mengatakan bahwa modernisasi mencakup suatu transformasi total kehidupan bersama yang tradisional atau pra modern. Modernisasi merupakan suatu bentuk perubahan sosial. Masyarakat petani merupakan bagian dari suatu komunitas yang paling peka dari segala irama perubahan yang pada dasarnya mereka menuntut suatu kepuasan/menguntungkan, mudah diserap bersifat ekonomis, praktis ataupun modern.

Gejala ini muncul pula bagi masyarakat petani kelapa di daerah Sulawesi Utara. Masyarakat ini merupakan kelompok mayoritas dimana kopra merupakan komoditas yang telah dikembangkan sejak dulu dan perlu diketahui bahwa tanaman kelapa merupakan produk andalan di bidang pertanian.

Fenomena yang terjadi di masyarakat petani yakni dengan tidak menentunya harga komoditi pertanian. Hal ini mengakibatkan masyarakat berspekulasi dengan pemenuhan kebutuhan keluarga termasuk di dalamnya pemenuhan kebutuhan akan kehidupan bermasyarakat, pendidikan, sosial budaya. Kehidupan sosial sering ditentukan oleh seberapa besar komoditi tersebut dapat mendatangkan uang. Kegotong-royongan sering dinilai dengan uang sementara budaya mapalus hanya diperkenankan oleh sebagian masyarakat yang berbeda pada tingkat pendapatan tertentu.

Di Desa Senduk terjadi suatu perubahan sosial yang di dalamnya seperti gotong- royong atau kerja bakti yang dulunya diikuti oleh seluruh anggota masyarakat tetapi saat ini kegiatan tersebut hanya diikuti oleh sebagian masyarakat tertentu. Hal ini disebabkan karena dahulu masyarakat umumnya petani, namun pada saat ini masyarakat sudah bermacam jenis pekerjaan: Petani, PNS, ABRI, Pedagang dan lain-lain. Begitu juga dalam hal mengelola tanaman kelapa terjadi perubahan sosial di dalam masyarakat, yang dulunya dikerjakan secara mapalus atau gotong royong namun pada saat ini dikerjakan secara individu atau secara sendiri-sendiri.

\section{Pengertian Perubahan Sosial}

Perubahan sosial merupakan perubahan kehidupan masyarakat yang berlangsung terusmenerus dan tidak akan pernah berhenti, karena tidak ada satu masyarakat pun yang berhenti pada suatu titik tertentu sepanjang masa. Artinya, meskipun para Sosiolog memberikan klasifikasi terhadap masyarakat statis dan dinamis, namun yang dimaksud masyarakat statis adalah masyarakat yang sedikit sekali mengalami perubahan dan berjalan lambat, artinya di dalam masyarakat statis tersebut tetap mengalami perubahan. Adapun masyarakat dinamis adalah masyarakat yang mengalami berbagai perubahan yang cepat.

Soekanto (2013) mengatakan perubahan sosial sebagai suatu variasi dari cara-cara hidup yang telah diterima, baik karena perubahan-perubahan kondisi geografis, kebudayaan material, komposisi penduduk, ideologi maupun karena adanya difusi ataupun penemuan-penemuan baru dalam masyarakat. Secara singkat Samuel Koenig mengatakan bahwa perubahan sosial menunjuk modifikasimodifikasi yang terjadi dalam pola-pola kehidupan manusia.

Ndraha (1990) mengartikan perubahan sosial itu sebagai perubahan lembaga-lembaga (institution) masyarakat, yaitu perubahan yang mempengaruhi sistem sosial, termasuk nilai sosial, sikap dan perilaku kelompok.

Selo Soemardjan dalam Soekanto (2013) merumuskan bahwa perubahan sosial adalah segala perubahan-perubahan pada lembaga-lembaga kemasyarakatan dalam suatu masyarakat, yang mempengaruhi sistem sosialnya, termasuk didalamnya nilai-nilai, sikap dan pola perilaku diantara kelompok-kelompok dalam masyarakat.

Tekanan pada definisi tersebut terletak pada lembaga-lembaga kemasyarakatan sebagai himpunan pokok manusia, perubahan-perubahan mana kemudian mempengaruhi segi-segi struktur masyarakat lainnya

Kingsley David dalam Soekanto damn Sulistyowati (2014) berpendapat bahwa perubahan sosial merupakan bagian dari kebudayaan, perubahan dalam kebudayaan mencakup semua bagian- 
ya yaitu : kesenian, ilmu pengetahuan, teknologi, filsafat dan seterusnya bahkan perubahanperubahan dalam bentuk serta aturan-aturan perubahan sosial dapat diketahui dari adanya ciri-ciri tertentu, antara lain:

1. Tidak ada masyarakat yang berhenti perkembangannya, karena setiap masyarakat mengalami yang terjadi secara lambat atau secara cepat.

2. Perubahan yang terjadi pada lembaga kemasyarakatan tertentu akan diikuti dengan perubahan-perubahan pada lembagalembaga sosial tadi sifatnya interdependen, maka sulit mengisolasi perubahan pada lembaga-lembaga sosial tertentu saja. Proses awal dan proses selanjutnya merupakan suatu mata rantai.

3. Perubahan-perubahan sosial yang cepat biasanya mengakibatkan disorganisasi yang bersifat sementara yang berada dalam proses penyesuaian diri. Disorganisasi akan diikuti oleh suatu reorganisasi yang mencakup pemantapan kaidah-kaidah dari nilai-nilai yang baru.

4. Perubahan-perubahan yang tidak dapat dibatasi pada bidang kebendaan atau bidang spiritual saja, karena bidang tersebut mempunyai kaitan timbal balik yang sangat kuat.

Dari sekian pendapat dari para ahli tentang pengertian perubahan sosial yang telah dikemukakan di atas maka ada beberapa unsur penting dapat diidentifikasikan yang mutlak sering terjadi dalam masyarakat petani. Hal tersebut adalah perubahan struktur dan sistem sosial, interaksi sosial dan tatanan sosial, pola-pola perilaku sosial atau norma.

\section{Struktur dan Sistem Sosial}

Firth dalam Taneko (1993) menyatakan bahwa struktur sosial adalah sesuatu pergaulan hidup manusia yang meliputi berbagai tipe kelompok yang terdiri dari banyak orang dan meliputi lembaga-lembaga didalamnya orang tersebut ambil bagian. Sedangkan Taneko (1993) sendiri mengemukakan 4 unsur-unsur pokok dari struktur sosial suatu masyarakat yakni :
1. Kelompok-kelompok sosial

2. Lembaga-lembaga sosial atau institusi

3. Kaidah-kaidah atau norma-norma sosial

4. Lapisan-lapisan sosial atau stratifikasi sosial

Dari pendapat ini dapat diaplikasikan bahwa kehidupan berkelompok masyarakat petani menggambarkan suatu struktur dan sistem sosial misalnya mapalus di Minahasa, kerukunan-kerukunan keluarga, arisan dan lain-lain.

\section{Interaksi Sosial}

Interaksi sosial merupakan salah satu faktor yang seiring berkembang sekaligus berubah dalam masyarakat baik masyarakat petani maupun masyarakat pada umumnya. Interaksi sosial merupakan bentuk umum dari proses sosial.

Interaksi sosial adalah kunci dari semua kehidupan sosial, tak akan mungkin ada kehidupan bersama-sama. Bertemunya orang perorangan secara badaniah belaka tidak akan menghasilkan pergaulan hidup dalam suatu kelompok sosial. Pergaulan hidup semacam itu baru akan terjadi apabila orang perorangan atau kelompok-kelompok manusia bekerja sama, saling berbicara, dan seterusnya untuk mencapai suatu tujuan bersama, mengadakan persaingan, pertikaian dan lain sebagainya.

Menurut Soekanto dan Sulistyowati (2014) interaksi sosial merupakan hubungan-hubungan sosial yang dinamis yang menyangkut hubungan antara orang-orang perorangan, antara kelompokkelompok manusia, maupun antara perorangan dengan kelompok manusia. Apabila 2 orang bertemu interaksi sosial dimulai saat itu. Mereka saling menegur, berjabat tangan, saling berbicara atau mungkin saling berkelahi.

Aktivitas-aktivitas semacam itu merupakan bentuk-bentuk interaksi sosial. Taneko (1993) mengemukakan bahwa dalam interaksi sosial mengandung makna tentang kontak secara timbal balik atau interstimulasi dan respon antar individuindividu dan kelompok-kelompok. Contoh, bila ada 2 petani kelapa bertemu, petani A merupakan petani kelapa yang berhasil sedangkan petani B merupakan petani kelapa yang gagal. Petani B bertanya kepada petani A menjelaskan pada petani B, sehingga dengan motivasi untuk menjadi petani kelapa yang berhasil maka petani $\mathrm{B}$ mengikuti apa yang diterapkan oleh petani, dari contoh di atas 
maka dapat dilihat interaksi sosial yang sangat terjadi di dalam masyarakat petani kelapa.

\section{Perilaku dan Norma Sosial}

Dalam kenyataan sehari-hari sulit untuk secara pasti dan tegas mengetahui nilai-nilai yang dianut oleh seseorang maupun kelompok orang atau suatu masyarakat (Taneko, 1993), Norma-norma dapat dianggap sebagai suatu konsep yang menyangkut semua keteraturan sosial yang berhubungan dengan evaluasi dari objek-objek, individuindividu, tindakan-tindakan dan gagasan.

Menurut Berry dalam Taneko (1993), unsur pokok dari suatu norman adalah tekanan sosial terhadap anggota-anggota masyarakat untuk menjalankan norma-norma tersebut. Latar belakangnya pemikirannya adalah bahwa apabila aturan-aturan yang tidak dikuatkan oleh desakan sosial, maka ia tidaklah dapat dianggap sebagai norma-norma sosial, sebab norma disebut norma sosial bukan saja karena telah mendapatkan sifat kemasyarakatannya, akan tatapi telah dijadikan patokan dalam perilaku.

Nilai-nilai sosial mengandung standart normative untuk perilaku, baik dalam hubungan dalam kehidupan pribadi maupun dalam hubungannya dengan kehidupan sosial. Secara sederhana norma-norma yang merupakan pedoman atau patokan perilaku itu sebenarnya yang bersumber dari nilai-nilai, oleh karena pedoman-pedoman perihal perilaku itu didasarkan pada konsepsi-konsepsi yang abstrak tentang apa yang baik dan apa yang buruk, apa yang seharusnya. Jadi dapat dinyatakan bahwa norma-norma merupakan wujud konkrit dari nilai-nilai, pedoman berisikan suatu keharusan, kebolehan dan suatu larangan oleh sebab itu, normanorma dapat pula disebut suatu standar atau skala yang terdiri dari berbagai kategori tingkah laku, norma-norma itu dapat di anggap suatu konsep yang menyangkut semua keteraturan sosial yang berhubungan dengan evaluasi dari obyek-obyek, individu-individu, tindakan-tindakan dan gagasan.

Secara sosiologis, norma-norma sosial itu tumbuh dari proses pemasyarakatan, hasil dari kehidupan bermasyarakat, individu dilahirkan dalam suatu masyarakat yang sudah ada sebelumnya. Dari uraian tersebut di atas dapat diaplikasikan bahwa berbagai fenomena dalam masyarakat petani merupakan nilai, perilaku dan norma sosial. Fenomena yang dimaksud adalah sifat-sifat kegotong royongan, kelembagaan atau organisasi petani termasuk aturan-aturan tentang baik buruk suatu perilaku. Masyarakat petani yang mendapatkan sanksi sosial disebabkan karena pelanggaran nilai, norma serta perilaku yang dimaksud.

\section{Mekanisme Perubahan}

\section{Perspektif Matrealistis}

Thorstein Veblen (1587-1929) hidup dengan sikap memprotes, ia melihat tatanan masyarakat sangat ditentukan oleh teknologi. Menurut Veblen, langkah penting dalam proses evolusi sosial adalah kemunculan pemilikan pribadi, munculah "kelas orang kaya", bentuk pemilikan pribadi yang mulamula adalah pemilikan wanita oleh laki-laki yang lebih kuat dalam komunitas, yang merampas wanita dalam peperangan. Veblen tak memikirkan perubahan mengarah pada tatanan sosial yang lebih baik. Ia membayangkan masyarakat lebih mudah mengalami kemunduran dari pada membuat kemajuan. Ada kesamaan pemikiran Veblen dan W.F. Ogburn (1986-1959). Ogburn juga memusatkan perhatian pada perkembangan teknologi dan ia menjadi terkenal karena mengembangkan ide Veblen mengenai ketinggalan kebudayaan.

Teori ketinggalan kebudayaan hanyalah salah satu aspek dari pemikiran Ogburn tentang perubahan. Penjelasanya tentang evolusi kebudayaan dipusatkan pada empat faktor: penemuan, pengumpulan, penyebaran, penyesuaian.

Yang menjadi pertanyaan sekarang adalah bagaimana cara teknologi mempengaruhi perubahan?

1. Teknologi meningkatkan alternatif kita

Teknologi baru membawa cita-cita yang sebelumnya tak dapat dicapai ke dalam alam kemungkinan, dan dapat mengubah kesukaran relative atau memudahkan menyadari nilai-nilai yang berbeda. Jadi dengan inovasi teknologi berarti masyarakat berhadapan dengan sejumlah besar alternative dan jika memilih alternative baru maka ia melalui perubahan besar di berbagai bidang.

2. Dengan mengubah pola-pola interaksi

Segera setelah inovasi teknologi diterima mungkin akan terjadi pergeseran penting terten- 
tu dalam pola interaksi, pergeseran yang dituntut oleh teknologi itu sendiri. Kecenderungan perkembangan teknologi menimbulkan masalah sosial baru adanya masalah ini menimbulkan semacam tanggapan yang dapat mengakibatkan berbagai perubahan untuk menyelesaikanya.

\section{Perspektif Idealistis}

Pada dasarnya pendirian marxis mengatakan ide muncul dari proses sosial dan kemudian menjadi penting dalam perkembangan sosial selanjutnya. Ide menjadi kuat bila ia mencerminkan kebutuhan dan kepentingan nyata manusia. Kebutuhan nyata manusia itu berakar di dalam kondisi sosial ekonomi dimana masyarakat itu hidup. Ide menentukan perilaku tetapi perilaku pun mempengaruhi pemikiran. Betapa seringnya kita mengatakan mengenai dominasai manusi selaku mekanisme perubahan, tetapi kita tidak dapat menyangkal bahwa manusia bertindak berdasarkan ide. Ide atau ideologi merupakan variabel independen bagi perubahan sosial, sebab ideology berperan dalam merintangi, membantu atau mengarahkan perubahan.

\section{Perspektif Internasional}

Konflik atau pertentangan dalam masyarakat mungkin pula menjadi sebab terjadinya perubahan sosial dalam masyarakat. Kelebihan tersebut dapat terjadi pertentangan antar kelompok ataupun antara generasi tua dengan generasi muda. Pertentanganpertentangan demikian itu kerap kali terjadi apalagi masyarakat yang sedang berkembang dari tahap tradisional ke tahap modern.

Generasi muda yang belum terbentuk kepribadianya, lebih mudah menerima unsur-unsur kebudayaan asing yang dalam beberapa hal mempunyai taraf yang lebih tinggi. Keadaan demikian menimbulkan perubahan-perubahan tertentu dalam masyarakat, misalnya pergaulan yang lebih bebas antara wanita dan pria atau kedudukan mereka yang kian sederajat di dalam masyarakat.

\section{Sumber Struktural}

Dari beberapa aspek struktur sosial yang dapat mempengaruhi arah perubahan. Pemerintah merupakan sumber utama perubahan, pemerintah bisa menjadi perubahan dan juga bisa menjadi kekuatan pendorong perubahan. Demikian juga sekelompok elit dapat juga menjadi perintang ataupun pendorong perubahan, bahkan pemuda dapat mempengaruhi perubahan sumbangan mereka terhadap ilmu pengetahuan dan berbagai jenis inovasi lain.

\section{Konsep Umum Tentang Petani}

Menurut Hermanto (1993) petani adalah setiap orang yang melakukan usaha untuk memenuhi sebagian atau seluruh kebutuhan kehidupan di bidang pertanian dalam arti luas yang meliputi usaha tani pertanian, peternakan, perikanan, (termasuk penangkapan ikan) dan pemungutan hasil laut. Orang yang disebut petani atau kedudukanya sebagai petani mempunyai fungsi banyak.

Ada beberapa ungkapan yang dapat disebut petani dalam kedudukanya, fungsinya ataupun peranannya, yakni:

a) Petani sebagai pribadi

b) Petani sebagai kepala rumah tangga

c) Petani sebagai guru

d) Petani sebagai pengelola usaha tani

e) Petani sebagai warga sosial atau kelompok

\section{Petani Sebagai Pribadi}

Berbeda dengan makhluk hidup yang lain, setiap orang termasuk juga petani selalu memiliki rasa, karsa dan cipta, yang memungkinkannya memiliki kehendak untuk di hargai, yang mendorong untuk berpikir, dan berkreasi guna mempertahankan dan menjamin kelangsungan kehidupan maupun untuk mencapai tingkat kesejahteraan lahir dan batin yang dinilai lebih memuaskan.

\section{Petani Sebagai Kepala Keluarga}

Petani yang sudah menikah dikaruniai anak akan berfungsi dan sekaligus sebagai anggota keluarga. Anggota kelurga jumlahnya tergantung pada se isi rumah yang menjadi tanggung jawabnya.

Sebagai kepala keluarga petani harus bertanggung jawab terhadap pemenuhan kesejahteraan seluruh anggota keluarganya. Ini merupakan tugas yang cukup berat, biasanya anggota keluarga lain membantu dalam mencari tambahan nafkah, membantu dalam proses usaha tani. Kebutuhan keluarga terse- 
but dapat berupah makanan, pakaian, tempat tinggal, pendidikan, kesehatan, rekreasi, sosial pajak dan lain-lain. Pangan umumnya dapat dipenuhi sebagian ataupun seluruhnya dari usaha tani tergantung pada kekuatan usaha taninya.

\section{Petani Sebagai Guru}

Perjalanan dan peekembangan pertanian di Indonesia menunjukan bahwa petani sekaligus sebagai guru dari anak-anaknya. Petani sebagian besar masuk di dalam kelompok-kelompok tani. Di dalam kelompok ini berkembang system belajar di antara petani. Petani yang maju menjadi guru, tempat bertanya bagi petani lain

\section{Petani Sebagai Pengelola Usaha Tani}

Peran petani sebagai pengelola usaha tani berfungsi mengambil keputusan dalam mengorganisir faktor-faktor produksi yang sesuai dengan pilihanya dari beberapa kebijakan produksi yang diketahui.

\section{Petani Sebagai Warga Sosial atau Kelompok dan Warga Negara}

Petani yang juga adalah manusia, umumnya sangat erat terikat oleh jalinan ikatan masyarakat lingkungan karena masyarakat adalah sumber kesentosaan petani yang:

- Menolong dalam mengahadapi masalahmasalah kritis.

- Membantu menyelesaikan pekerjaan-pekerjaan usaha tani karena itu, dalam setiap langkah kegiatan petani diperlukan persetujuan sosial terlebih dahulu, seperti tradisi, adat istiadat, agama, kepercayaan dan lain-lain.

Ekonomi keluarga petani adalah sebuah usaha pertanian yang sering dijumpai. Sebagai kesatuan produksi dan konsumsi, mereka terorganisir menurut masing-masing struktur keluarga tani yang berlaku. Tetapi ada juga proses kebalikan dari penyesuaian organisasi keluarga dalam rangka membuka peluang untuk memenuhi kebutuhan keluarga. Seperti yang dikemukakan Planck (1993) bahwa keluarga memperkecil atau juga memperluas lingkaran anggota keluarganya agar dapat memenuhi kebutuhannya dan menyesuaikan diri dengan situasi sosial ekonomi yang sering berubah.
Dijelaskan pula bahwa yang lebih sering terjadi adalah anggota keluarga tani kecil dalam jangka waktu tertentu bekerja di luar usaha pertanian keluarga agar menambah penghasilan.

\section{Konsep kepadatan penduduk}

Soekanto (2013) mengemukakan bahwa penduduk yang heterogen atau masyarakat yang terisi dari kelompok-kelompok sosial yang mempunyai latar belakang kebudayaan berbeda, ras yang berbeda, ideologi yang berbeda dan seterusnya, mempermudah terjadi pertentangan-pertentangan yang mengandung kegoncangan-kegoncangan. Keadaan demikian menjadi pendorong bagi terjadi perubahan-perubahan dalam masyarakat.

Mengamati jumlah penduduk yang kini makin banyak mengakibatkan persediaan lahan atau pembagian lahan makin kecil.

Hal ini berdampak pula pada jumlah pendapatan petani tersebut. Pengaruh pada perubahan sosial adalah mereka tidak dapat memenuhi tuntutantuntutan sosial yang memerlukan biaya.

Planck (1993) menjelaskan bahwa untuk teknologi produksi tertentu penambahan jumlah penduduk dalam sumber daya lahan yang terbatas menyebabkan penurunan pendapatan antara mereka yang tidak memiliki lahan di atas satu pihak dan memilik lahan di pihak lain, yang dipengaruhi oleh sifat hak pemilik kan lahan. Dijelaskan bila dalam hak-hak pemilik terbuka, penambahan penduduk menyebabkan penurunan hasil panen dan peningkatan biaya sosial.

\section{Rumusan Masalah}

Telah terjadi perubahan dalam petani kelapa. Bagaimana petani penghasil kopra ini akan mengelolah penghasilan yang diperolehnya untuk memenuhi kebutuhan baik secara individu, keluarga, kelompok termasuk didalamnya untuk memenuhi tuntutan sosial dalam masyarakat.

Suatu gambaran fenomena pada Desa Senduk yakni seringkali kegotong-royongan (kerja bakti) diukur dengan uang, pada saat tertentu pula terjadi gejala konsumtif atau sebagai contoh bahwa kebiasaan belanja di pasar tradisional diubah ke pasar modern.

Melihat situasi dan keadaan ini, menarik untuk diteliti bagaimana perubahan sosial dalam 
masyarakat khususnya petani kelapa yang telah terjadi 20 tahun terakhir ini.

Tujuan dan Manfaat Penelitian

Penelitian ini bertujuan untuk mengetahui perubahan sosial yang terjadi pada petani kelapa. Pada hasil penelitian ini di harapkan dapat memberi sumbangan bagi pengembangan ilmu pengetahuan yang berkaitan dengan pemberdayaan manusia dalam menghadapi era modernisasi khusunya dalam mempertahankan nilai sosial budaya masyarakat tradisional.

\section{METODOLOGI PENELITIHAN}

\section{Metode Pengumpulan Data}

Penelitan ini menggunakan data primer yang dapat diperoleh melalui wawancara mendalam berdasarkan daftar pertanyaan (kuesioner) dan dilengkapi dengan data sekunder yang diperoleh dari kantor Desa Senduk.

\section{Metode pengambilan sampel}

Metode pengambilan dilakukan dengan cara simple random sampling atau acak sederhana, dengan jumlah responden 20 petani kelapa.

\section{Konsepsi pengukuran variabel}

Variabel-variabel yang akan di ukur dalam penelitian ini adalah:

$>$ Karakteristik responden, dilihat dari umur dan pendidikan.

$>$ Perubahan sosial dilihat dari struktur sosial, dan perubahan yang terjadi dari masa lampau sampai masa kini.
Perilaku sosial dilihat dari : Budaya, Peraturan-peraturan, Adat istiadat

\section{Metode analisis data}

Data yang diperoleh akan dianalisis secara deskriptif dan disajikan dalam bentuk table.

\section{Waktu dan lokasi penelitian}

Penelitian ini berlangsung selama 3 bulan sejak persiapan sampai penyusunan laporan. Penelitian ini dilaksanakan di Desa Senduk Kecamatan Tombariri dari bulan Maret sampai dengan bulan Mei 2015

\section{HASIL DAN PEMBAHASAN}

\section{Deskripsi Umum Wilayah Penelitian}

\section{Letak dan Luas Daerah}

Desa Senduk adalah salah satu desa yang ada di Kecamatan Tombariri Kabupaten Minahasa. Adapun letak dan batas wilayah Desa Senduk yang terdiri dari:

Sebelah Utara dengan Desa Ranowangko

Sebelah Barat dengan Desa Po'Opoh

$>$ Sebelah Timur dengan Desa Lolah dan Desa Ranotongkor

Sebelah Selatan dengan Desa Munte dan Desa Tangkunei 
Perubahan Sosial pada Petani Kelapa......(Richi R. Sembel, Martha M. Sendow, Welson M. Wangke, Jean F.T. Timban)

Tabel 1. Jumlah Penduduk Di Desa Senduk

\begin{tabular}{cccccc}
\hline & & \multicolumn{3}{c}{ JUMLAH PENDUDUK } & \\
\cline { 2 - 5 } No & Jaga & L & P & TOTAL / (\%) & Jumlah (KK) \\
\hline 1 & 1 & 130 & 118 & $248 / 8,6$ & $68 / 8,4$ \\
2 & 2 & 121 & 110 & $231 / 8,8$ & $71 / 8,3$ \\
3 & 3 & 120 & 109 & $229 / 8,1$ & $63 / 7,8$ \\
4 & 4 & 118 & 110 & $228 / 7,9$ & $66 / 8,2$ \\
5 & 5 & 107 & 104 & $211 / 7,3$ & $65 / 8,8$ \\
6 & 6 & 116 & 127 & $243 / 8,5$ & $62 / 7,7$ \\
7 & 7 & 116 & 105 & $221 / 7,7$ & $64 / 7,9$ \\
8 & 8 & 154 & 128 & $282 / 9,8$ & $72 / 8,9$ \\
9 & 9 & 155 & 121 & $276 / 9,6$ & $66 / 8,2$ \\
10 & 10 & 124 & 112 & $236 / 8,2$ & $76 / 9,4$ \\
11 & 11 & 110 & 109 & $219 / 7,6$ & $64 / 7,9$ \\
12 & 12 & 123 & 110 & $233 / 8,1$ & $67 / 8,3$ \\
\hline & Jumlah & 1494 & 1363 & $2857 / 100$ & $804 / 100$ \\
\hline
\end{tabular}

Sumber Data: Dari Kantor Desa Senduk, 2014

Desa Senduk mempunyai luas wilayah \pm $10.000 \mathrm{Ha}$. Yang terbagi atas wilayah hutan dan pemukiman, dan curah hujan rata-rata mencapai $1000-2200 \mathrm{~mm} /$ tahunya dengan suhu $28-32^{0} \mathrm{C}$.

\section{Penduduk}

Berdasarkan jumlah penduduk di Desa Senduk sebanyak 2,857 jiwa dengan total jumlah kepala keluarga 804 KK yang menempati 12 jaga bahwa jumlah penduduk laki-laki lebih besar dari pada jumlah penduduk perempuan (Tabel 1). Jumlah penduduk laki-laki yang lebih banyak berada di Jaga 9 sebanyak 155 orang dan yang paling rendah di jaga 5 dengan jumlah 107 orang. Sedangkan jumlah penduduk perempuan terbanyak berada pada jaga 8 dengan jumlah 128 orang dan jumlah penduduk perempuan terendah berada pada jaga 5 dengan jumlah 104 orang.

\section{Pendidikan}

Tingkat pendidikan yang dimiliki oleh masyarakat di Desa Senduk berdasarkan data yang di ambil bervareasi mulai SD, SLTP, SLTA, PT.
Sarana pendidikan yang terdapat di Desa Senduk yaitu satu bangunan SD dan satu bangunan SLTP.

Tabel 2. Menunjukan bahwa tingkat pendidikan di Desa Senduk masih sangat rendah yang setara PT yang berjumlah 136 orang, sedangkan penduduk berpendidikan SD 997 orang, sedangkan penduduk berpendidikan SMP 1,051 orang.

Tabel 2. Penduduk Menurut Tingkat Pendidikan di Desa Senduk

No Tingkat Pendidi- Jumlah Presentase (\%)

\begin{tabular}{cccc}
\multicolumn{4}{c}{ kan } \\
\hline 1 & Tidak Tamat SD & 104 & 3,87 \\
2 & SD & 997 & 37,15 \\
3 & SMP & 1,051 & 39,17 \\
4 & SMA & 395 & 14,72 \\
5 & PT & 136 & 5,06 \\
\hline & Jumlah & 2,683 & 100
\end{tabular}

Sumber: Data Kantor Desa Senduk 2014 


\section{Mata Pencaharian}

Sebagian besar penduduk di Desa Senduk bermata pencharian sebagai petani di samping itu ada juga yang berprofesi sebagai buruh tani, Pegawai Negeri, peternak dan lain.

Tabel 3. Menunjukan bahwa jumlah mata pencaharian lebih tinggi adalah petani sebanyak 717 orang. Sedangkan mata pencaharian yang paling rendah adalah bidan sebanyak 2 orang.

Tabel 3. Jenis Mata Pencarian Penduduk di Desa Senduk

\begin{tabular}{clcc}
\hline No & Jenis pekerjaan & Jumlah & $\begin{array}{c}\text { Prsentase } \\
(\%)\end{array}$ \\
\hline 1 & Petani & 717 & 53,7 \\
2 & Peternak & 6 & 0,45 \\
3 & Kerajinan kecil & 16 & 1,20 \\
4 & Mantri & 18 & 1,35 \\
& kesehatan & 2 & 0,15 \\
5 & Bidan & 187 & 14,2 \\
6 & PNS & 112 & 9,15 \\
7 & Buruh & 86 & 6,45 \\
8 & Pedagang & 24 & 1,80 \\
9 & Tukang & 31 & 2,32 \\
10 & TNI/POLRI & 134 & 10,5 \\
11 & Pensiunan & 1333 & 100 \\
\hline
\end{tabular}

Sumber: Data Kantor Desa Senduk 2014

\section{Fasilitas Bangunan}

Fasilitas yang dimiliki oleh masyarakat Desa Senduk berdasarkan data yang di ambil aneka ragam dari sarana pendidikan, tempat ibadah bahkan kantor pemerintahan.

Tabel 4 menunjukan bahwa fasilitas atau sarana terbanyak yang ada di Desa Senduk adalah sarana Gedung Gereja yang berjumlah 4 buah yang terdiri dari 1 buah Gedung Gereja GMIM, 1 buah Gedung Gereja Pantekosta, 1 buah Gedung Gereja Alfa Omega dan 1 buah Gedung Gereja Katolik.

\section{Tabel 4. Fasilitas Bangunan di Desa Senduk}

\begin{tabular}{lll}
\hline No & Jenis Bangunan & Jumlah \\
\hline 1 & Sekolah & 3 \\
2 & Kantor Hukum Tua & 1 \\
3 & Gereja & 4 \\
4 & Balai Serbaguna & 1 \\
\hline & Jumlah & 9
\end{tabular}

Sumber: Data Kantor Desa Senduk 2014

\section{Karakteristik Responden}

Dari hasil penelitian yang telah dilakukan terhadap 20 karakterstik responden dalam perubahan sosial yang berada di Desa Senduk, karakteristik dilihat dari tingkat umur, pendidikan, struktur sosial, interaksi dan teknologi informasinya sebagai berikut.

\section{Umur}

Umur merupakan satu karakteristik yang mempengaruhi perubahan sosial bagi petani kelapa untuk bekerja secara efektif. Petani yang berumur di bawah 50 tahun memiliki fisik yang lebih kuat dan cara berpikir yang lebih berkembang maju dan terarah dibanding dengan petani yang berumur di atas 50 tahun. Dari hasil penelitian diperoleh umur kelompok responden petani berkisar antara 22-70. Kelompok umur responden dapat dilihat pada tabel 5 .

Tabel 5. Kelompok Umur dan Responden

\begin{tabular}{cccc}
\hline No & $\begin{array}{c}\text { Umur Re- } \\
\text { sponden } \\
\text { (tahun) }\end{array}$ & $\begin{array}{c}\text { Jumlah Re- } \\
\text { sponden } \\
\text { (orang) }\end{array}$ & $\begin{array}{c}\text { Presentase } \\
(\%)\end{array}$ \\
\hline 1 & $17-25$ & 6 & 30 \\
2 & $25-50$ & 8 & 40 \\
3 & $>51$ & 6 & 30 \\
& Jumlah & 20 & 100 \\
\hline
\end{tabular}

Sumber: Diolah dari Data Primer 2015 
Tabel 5. Menunjukan bahwa jumlah responden yang menjadi sampel berada pada usia produktif. Dapat dilihat dari jumlah responden yang berumur 25 - 50 tahun sebanyak 8 orang. Sedangkan responden di bawah umur 17 - 25 tahun dan umur $>51$ tahun masing-masing berjumlah 6 orang.

\section{Pendidikan}

Sebagaimana diketahui bahwa pendidikan merupakan proses belajar dengan menerima inputinput dari luar yang dapat menunjukan pola-pola befikir positif.Peranan pendidikan dalam usia peningkatan kualitas penduduk dan sumber daya manusia (SDM) sangat penting dan dibutuhkan sejalan dengan kemajuan teknologi yang semakin maju. Karena itu yang dibutuhkan pengetahuan yang maju untuk menciptakan suatu perubahan dalam kehidupan bermasyarakat khususnya untuk meningkatkan pendapatan.

Tabel 6. Jumlah Responden Menurut Tingkat Pendidikan

\begin{tabular}{lccc}
\hline No & $\begin{array}{c}\text { Tingkat Pen- } \\
\text { didikan }\end{array}$ & $\begin{array}{c}\text { Responden } \\
\text { Respontase }\end{array}$ & $\begin{array}{c}\text { Presentas } \\
(\%)\end{array}$ \\
\hline 1 & $\begin{array}{c}\text { Tidak tamat } \\
\text { SD }\end{array}$ & 6 & 30 \\
2 & SD & 8 & 40 \\
3 & SMP & 4 & 20 \\
4 & SMA & 2 & 10 \\
5 & PT & - & - \\
\hline & Jumlah & 20 & 100 \\
\hline
\end{tabular}

Sumber: Diolah dari Data primer 2015

Tabel 6 menunjukan bahwa responden terbanyak memiliki pendidikan SD sebanyak 8 orang, sedangkan responden paling rendah adalah 2 orang dengan tingkat pendidikan SMA. bahwa tingkat penyerapan responden petani kelapa dalam hal yang baru serta pengambilan keputusan dalam setiap masalah sudah cukup baik. Ditunjuhkan pada responden petani kelapa mulai mencoba memproduksi kopra putih walaupun mereka merasa hal tersebut sangat merepotkan dan juga para petani kelapa di Desa Senduk mulai mengembangkan usahatani dengan menanam tanaman selain kelapa.

\section{Perubahan Sosial}

Moore dalam Launer (1993) mendefinisikan perubahan sosial sebagai perubahan penting dari struktur sosial. Yang dimaksud dengan struktur sosial adalah pola-pola perilaku dan interaksi sosial.Pada konsep ini akan ditekankan pada struktur sosial yang digambarkan dalam pola-pola perilaku dan interaksi sosial.

\section{Interaksi Sosial dan tatanan Sosial}

Interaksi sosial dan tatanan sosial merupakan dua faktor yang sering berkembang sekaligus sering berubah dalam masyarakat baik masyarakat petani maupun masyarakat pada umumnya. Interaksi sosial dan tatanan sosial yang mengalami perubahan atau pergeseran di daerah penelitian dapat dilihat pada Tabel 7.

Tabel 7 menunjukan bahwa di Desa Senduk ada satu kebiasaan untuk saling memberi bumbu masakan antara lain (cabe dan garam,) jika ada tetangga yang sudah kehabisan bumbu masakan maka yang bersangkutan akan meminta kepada tetangganya.

Mapalus di Desa Senduk juga mengalami perubahan pada awalnya setiap kelompok mapalus mempunyai seseorang pemimpin dan untuk memanggil anggota mapalus lainnya mereka menggunakan kerang besar yang biasa ditiup, pemimpin ini berkewajiban untuk memberi ganjaran bagi anggota mapalus yang terlambat tiba di tempat kerja, ganjaran yang diberikan berupa pukulan dengan menggunakan rotan di kaki, sebaliknya jika ketua yang melakukan pelanggaran maka anggota mapalus akan memukul pimpinan tersebut dengan tangan. Tetapi pada saat ini hal tersebut tidak ada lagi karena sudah dianggap melanggar HAM dan digantikan dengan dikenakan sanksi berupa penambahan jam kerja sesuai dengan keterlambatannya, sedangkan untuk memanggil anggota mapalus mereka saling memberitahukan. 


\section{Tabel 7 Perubahan Interaksi Sosial dan Tatanan Sosial}

\begin{tabular}{|c|c|}
\hline 1980-an & 2000-an \\
\hline $\begin{array}{l}\text { 1. Saling Memberi Bumbu Masakan } \\
\text { Misalnya (Cabe dan garam) }\end{array}$ & - $\quad$ Sama Sekali Tidak Ada Perubahan \\
\hline 2. Mapalus & \\
\hline 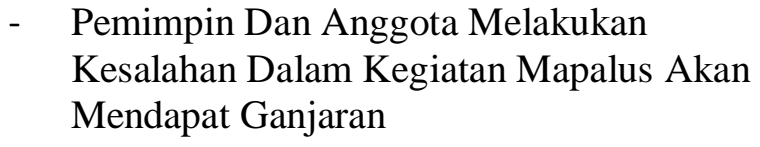 & $\begin{array}{l}\text { - } \quad \text { Pemimpin Dan Anggota Melakukan } \\
\text { Kesalahan Mendapat Sanksi }\end{array}$ \\
\hline $\begin{array}{ll}\text { - } & \text { Anggota Mapalus Semua Petani Kelapa } \\
\text { - } & \text { Waktu Kerja } 5 \text { Jam (Petani) } \\
\text { - } & \text { Semua Anggota Hadir Pada Setiap } \\
& \text { Kegiatan Mapalus Tanpa Ada Alasan }\end{array}$ & $\begin{array}{ll}\text { - } & \text { Semua Anggota Mapalus Adalah Petani } \\
\text { - } & \text { Waktu Kerja Selama } 6 \text { Jam Untuk Petani } \\
\text { - } & \text { Semua Anggota Hadir Setiap Kegiatan } \\
& \text { Mapalus Memberi Izin Dengan Menganti- } \\
\text { kan Tenaga Kerja }\end{array}$ \\
\hline 3. Kerja Bakti (Jumat Bersih) & \\
\hline 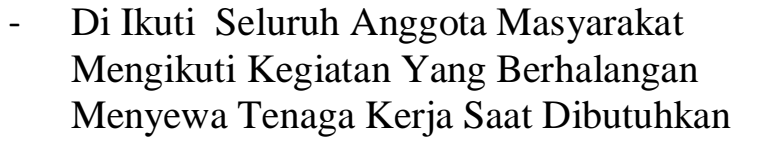 & $\begin{array}{l}\text { - } \quad \text { Tidak Semua Anggota Masyarakat Mengi- } \\
\text { kuti Kegiatan, Namun Mengantikan Tenaga } \\
\text { Kerja Lain }\end{array}$ \\
\hline 4. Komunikasi Bebas Dilakukan & $\begin{array}{l}\text { - Komunikasi Mulai Dibatasi Menggunakan } \\
\text { Telepon }\end{array}$ \\
\hline
\end{tabular}

Sumber: Hasil olahan data primer, 2015

Kebiasaan-kebiasaan dalam masyarakat juga terjadi perubahan-perubahan, misalnya kerja bakti yang kadang penekanannya bukan pada bentuk kerja sama kelompok tetapi mulai pada penyelesaian secara pribadi. Artinya karena petani telah memiliki penghasilan yang cukup maka dalam kegiatan mereka hanya menyewa tenaga kerja bakti dan tidak melibatkan diri secara langsung di dalam kelompok. Perilaku ini telah mengikis budaya kelompok atau kerja sama yang dahulu menjadi kebiasaan di desa. Apabila didapat anggota sanksi sosialnya yaitu menjadi bahan pembicaraan antara anggota masyarakat dan akan tertekan secara psikologis dalam pergaulan antar masyarakat.

Kerja bakti pada tahun 1980-an dilakukan di sembarang waktu di saat ada kegiatan yang harus diselesaikan tapi pada saat ini kegiatan tersebut dilakukan pada hari jumat yang dinamakan 'Jumat Bersih'. Namun program ini membuat partisipasi masyarakat sekarang berkurang dari tahun ke tahun sebelumnya.

Pengambilan keputusan sosial dalam masyarakat awalnya didasarkan pada adat stiadat yang berlaku, misalnya untuk melakukan program Desa maka sebelumnya di dalam rapat umumnya dihadiri seluruh masyarakat tanpa melihat strktur sosial. Hal ini kemudian berkembang dimana yang mengikuti rapat umum masyarakat yang mewakili kelompok tertentu. Perubahan atau pergeseran ini terjadi karena kapasitas tempat pertemuan yang tidak memungkinkan untuk menumpang masyarakat. Selain itu juga dalam mengambil keputusan dalam masyarakat sudah di wakilkan pada tiap-tiap kepala jaga.

Kondisi seperti ini sangat mempengaruhi dalam pengambilan keputusan masyarakat desa, pengaruh tersebut telah memungkinkan sebagian masyarakat melaksanakan pekerjaannya dan sebagian mengikuti pertemuan. Demikian pula pelaksa- 
Perubahan Sosial pada Petani Kelapa......(Richi R. Sembel, Martha M. Sendow, Welson M. Wangke, Jean F.T. Timban)

naan keputusan hanya dilakukan sebagian masyarakat terutama yang mengikuti langsung keputusan-

keputusan tersebut.

\section{Tabel 8 Perubahan Pola-pola Perilaku di Desa Senduk}

\begin{tabular}{|c|c|}
\hline $\begin{array}{c}\text { Sebelum } \\
\text { Perubahan Sosial }\end{array}$ & $\begin{array}{c}\text { Sesudah } \\
\text { Perubahan Sosial }\end{array}$ \\
\hline $\begin{array}{l}\text { Bila ada penyimpangan- } \\
\text { penyimpangan sosila maka akan di- } \\
\text { usir dari Desa Senduk }\end{array}$ & 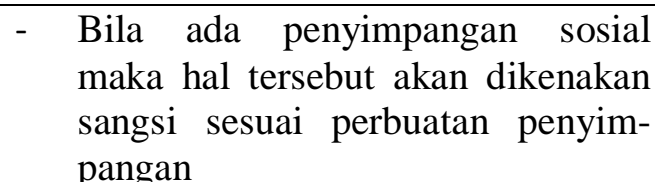 \\
\hline $\begin{array}{l}\text { Hasil panen petani kelapa meningkat } \\
\text { dan tidak ada pencurian yang } \\
\text { mengakibatkan kerugian }\end{array}$ & $\begin{array}{l}\text { - Hasil panen petani kelapa saat ini } \\
\text { tidak aman lagi dikarenakan ban- } \\
\text { yak pencurian }\end{array}$ \\
\hline - Pola hidup pada kegiatan produktif & $\begin{array}{l}\text { - Pola hidup mengarah pada kegiatan } \\
\text { konsumtif }\end{array}$ \\
\hline
\end{tabular}

Sumber: Diolah dari Data Primer, 2015

Keluarga petani pada umumnya dalam komunikasi mulai kebutuhan telekomunikasi dengan menggunakan telepon. Hal ini menyebabkan komunkasi sosial antar warga, kelompok dan tetangga terkesan renggang. Misalnya seseorang warga yang ingin menyampaikan berita kepada warga lainnya di lingkungan tersebut tidak disampaikan dengan cara komunikasi langsung atau interaksi langsung tetapi disampaikan dengan cara

Tabel 8 menunjukkan bahwa pola-pola perilaku yang ada pada masyarakat juga mengalami perubahan atau pergeseran. Pada tahun 1980-an di Desa Senduk tanaman kelapa tidak pernah mengalami pencurian namun sekarang ini sering ditemukan. Hal ini disebabkan karena tutunan kebutuhan yang harus dipenuhi oleh masyarakat tersebut namun kemampuan yang dimilikinya sudah terbatas.

Pada tahun 1980-an bila ada masyarakat yang melakukan penyimpangan sosial maka akan ditindak oleh lembaga masyarakat yang berwenang namun pada saat ini hal tersebut dibiarkan, dikarenakan sudaha ada peraturan-peraturan yang ada, demikian juga pola hidup petani telah berubah. $\mathrm{Pa}-$ da tahun 1980-an bila petani mempunyai uang akan menggunakan untuk kegiatan produksi berupa melakukan peremajaan pohon kelapa namun komunikasi langsung atau interaksi sosial, bahwa saling bertemu secara langsung merupaka hal yang diwajibkan pada masa lampau.

\section{Pola-pola Perilaku}

Pola-pola perilaku yang berkembang pada masyarakat di daerah penelitian yang telah mengalami prubahan atau pergeseran dapat dilihat di Tabel 8.

sekarang bergeser ke system konsumtif yaitu intensitas pesta yang sudah meningkat.

Keluarga petani kelapa pada umumnya mulai menggunakan pasar modern memenuhi kebutuhan rumah tangga misalnya belanja di Manado untuk membeli peralatan elektronik berupa TV,DVD.

Ada suatu kebiasaan pada petani kelapa di Desa Senduk dalam hal menanam kelapa. Dalam menanam kelapa mereka melihat terlebih dahulu apakah di malam hari terdapat bulan purnama dan jika tidak maka keesokan harinya mereka belum akan menanam kelapa. Hal ini disebabkan karena pada saat itu hama-hama tersebut akan berkembang biak. Saat ini kebiasaan tersebut jarang dilakukan karena saat petani ingin menanam mereka langsung tanam. Hal ini dikarenakan sudah ada pemberantasan hama dan penyakit tumbuhan. 
Tabel 9. Perubahan Perilaku Pada Petani Kelapa di Desa Senduk

\begin{tabular}{|c|c|}
\hline $\begin{array}{c}\text { Sebelum } \\
\text { Perubahan Sosial }\end{array}$ & $\begin{array}{c}\text { Sesudah } \\
\text { Perubahan Sosial }\end{array}$ \\
\hline $\begin{array}{l}\text { - Pembibitan kelapa masih digantung me- } \\
\text { makai bambu. }\end{array}$ & $\begin{array}{l}\text { - Pembibitan kelapa sudah memakai poly- } \\
\text { bag }\end{array}$ \\
\hline $\begin{array}{l}\text { - Penanaman kelapa dilakukan } \\
\text { dengan cara melihat bulan purnama }\end{array}$ & $\begin{array}{l}\text { - Penanaman kelapa dilakukan dengan cara } \\
\text { melihat bulan purnama (sama sekali tidak } \\
\text { ada perubahan) }\end{array}$ \\
\hline $\begin{array}{l}\text { - Cara panen dilakukan sendiri, tanpa me- } \\
\text { nyewa atau memperkerjakan orang lain. }\end{array}$ & $\begin{array}{l}\text { - Saat ini cara memanen kelapa Saat ini } \\
\text { panen kelapa sudah memperkerjakan } \\
\text { orang atau bisa di bilang menyewa orang } \\
\text { untuk memanen kelapa. }\end{array}$ \\
\hline $\begin{array}{l}\text { - Transportasi hasil panen menggunakan } \\
\text { gerobak sapi }\end{array}$ & $\begin{array}{l}\text { - Saat ini transportasi hasil panen sudah } \\
\text { menggunakan kendaraan (truk) }\end{array}$ \\
\hline $\begin{array}{l}\text { - Pembuatan kopra masih kopra asap dengan } \\
\text { menggunakan vorno }\end{array}$ & $\begin{array}{l}\text { - Pembuatan kopara sudah dikenalkan } \\
\text { dengan kopra putih tetapi kopra ini masih } \\
\text { tergolong repot dan susah diserap oleh } \\
\text { petani }\end{array}$ \\
\hline
\end{tabular}

Sumber: Data Diolah dari Data Primer,2015

Untuk pembibitan kelapa, kelapa hanya digantung dan setelah terlihat pertumbuhan akar baru ditanam namun saat ini pembibitan banyak yang sudah menanam di polybag, karena hasilnya lebih bagus dari pada pembibitan dengan cara digantung. Demikian juga pemeliharaan kebun baru pembersihan, pada tahun 1980-an hanya menggunakan cangkul sekarang sudah ada yang menggunakan alat pemotongan rumput.

Transportasi untuk panen kelapa sudah mengalami perubahan yang pada tahun 2000-an dari kebun sampai ke tempat penjualan hanya menggunakan gerobak namun saat ini untuk pengangkutan kelapa atau kopra di tepi jalan dari kebun sudah menggunakan kendaraan roda empat seperti truk.
Begitu juga dalam pola tanaman petani terjadi perubahan, pada awalnya pola tanaman petani adalah monokultur namun pada saat ini sudah ke pola intercopping hal ini disebabkan karena menurunnya jumlah penghasilan kelapa juga disebabkan keinginan dari para petani untuk meningkatkan penghasilan dan pendapatan. Selain merubah pola tanam ke intercropping para petani disana juga menambah penghasilan atau pendapatan mereka dengan menjadi tukang ojek.

\section{Kepadatan Penduduk}

Pada konsep ini ditekankan sejauh mana perkembangan jumlah penduduk yang mengakibatkan heterogenisasi penduduk sehingga berdampak pada tatanan sosial dalam masyarakat. 
Masuknya penduduk dari daerah lain (terutama dari kota-kota besar) dan membangun rumah, mengakibatkan masuknya budaya-budaya baru.

Hal ini terjadi karena penduduk baru sangat sulit dan kaku melakukan interaksi sosial seperti yang memberi kebutuhan sehari-hari seperti rempah-rempah, bahan lauk pauk, pintu rumah sering tertutup mengakibatkan terbatasnya saling mengunjungi antar warga dan antar tetangga.

\section{KESIMPULAN DAN SARAN}

\section{Kesimpulan}

Perubahan sosial yang terjadi pada petani kelapa adalah pola-pola perilaku yang meliputi cara bertani kelapa dari pembibitan, penanaman kelapa, alat transportasi, sampai saat waktu panen dan interaksi sosial yang meliputi mapalus dan kerja bakti. Kepadatan penduduk juga menyebabkan terjadinya perubahan sosial dengan peralihan penggunaan lahan pertanian ke lahan pemukiman yang berada di Desa Senduk.

\section{Saran}

Kebiasan yang baik seperti Mapalus dan Kerja bakti dipertahankan serta dipelihara agar tidak terkikis oleh budaya-budaya yang masuk seiring dengan perkembangan zaman.

\section{DAFTAR PUSTAKA}

Danin, Sudarwan, 1997. Metode Penelitian Untuk Ilmu-ilmu Perilaku, Bumi

Aksara. Jakarta.

Djoyohadikusumo, Sumitro, 1990. Perkembangan

Pemikiran Ekonomi Dan Teori

Ekonomi Pertumbuhan dan Ekonomi

Pengembangan. LP3ES, Jakarta.

Herimanto, Winarno, 2009. Ilmu Sosial \& Budaya

Dasar. Jakarta. PT. Bumi Akasara.

Hermanto, Fadholi, 1993. Ilmu Usaha Tani,

Penebar Swadaya. Jakarta

Hoogvelt, A.M.M, 1995. Sosiologi Masyarakat

Sedang Berkembang. PT. Raja Grafindo

Persada. Jakarta.
Nawawi, H, 1991. Perspektif Tentang Bidang Sosial. Gajah Mada University Press. Yogyakarta.

Ndraha, Taliziduhu, 1990. Pembangunan

Masyarakat: Mempersiapkan Masyarakat

Tinggal Landas, Rineke Cipta, Jakarta.

Nur Djazifah ER; M.Si, 2012. Proses Perubahan

Sosial Di Masyarakat. Modul

Pembelajaran Sosiologi. Lembaga

Penelitian dan Pengabdian Kepada

Masyarakat Universitas Negeri

Yogyakarta Lembaga.

Sajogyo, Pujiwati, 1995. Sosiologi Pedesaan.

Gajah Mada University Press

Yogyakarta

Soekanto, Soeryono dan Sulistyowati, Budi, 2014.

Sosiologi sebagai Pengantar, Raja

Grafindo. Jakarta.

Susanto, A.S, 2000. Pengantar Sosiologi dan Perubahan Sosial, Bina Cipta, Bandung

Suryabrata, Sumadi, 1982. Psikologi Kepribadian. Raja Grafindo Persada. Jakarta.

Taneko, S. B, 1993. Struktur dan Proses Sosial, Suatu Pengantar Sosiologi Pembangunan, PT. Raja Grafindo Persada Jakarta.

Winardi, Sudrajad, 1994. Mengajukan dan

Mengelola Kredit Usaha Tani, PT.

Penebar Swadaya, Jakarta.

Wolf, Eric R, 1985. Petani: Suatu Tinjauan Antropologis, CV. Raja Wali Jakarta. 